UDC 811.161.2:81'367.622

DOI https://doi.org/10.32999/ksu2663-2691/2020-82-12

\title{
CONNECTING PROPERTIES OF NOUNS
}

\author{
Lebed Yuliia Borysivna, \\ Candidate of Philological Sciences, \\ Head of the Department of Foreign Literature \\ and Foundations of Rhetoric \\ Vinnytsia Humanities Pedagogical College \\ iulialebed7@gmail.com \\ orcid.org/000-0002-8325-3462
}

Purpose. The article is devoted to connecting possibilities of Noun. The functional method helps to solve syntactical problems that regard to the structure of a sentence. Ukrainian linguistics has many studies that are devoted to Verb possibility of making sentences. The purpose of the article is to describe the possibilities of Noun to form Noun nomination of a few words.

Methods. The main methods of the study were: a descriptive method; comparison method; modeling method; method of distributive analysis.

Results. Noun has one of the central places in the system of the parts of speech. It can denote items and can be the main component of a sentence. Noun is one of the components that organize a sentence.

Most semantic unities are based on synsemantical Noun, that can't nominate object denotations. This property contributes to the forming of unities of different structure with the synsemantical Noun. Ukrainian synsemantical Nouns are formed from synsemantical Verbs, some absolutive Nouns with certain meaning and nouns with figurative sense. Synsemantical Nouns can't be formed from Verbs that mean nature state.

In Noun nomination of a few words the Noun forms strong position for depended component. This component compensates the Noun synsemantics. According to these depended components we can distinguish such models of Noun nomination of a few words: non prepositional Noun / Pronoun model, prepositional Noun / Pronoun model, infinitive model.

Synsemantical Nouns manifest selectivity according to dependent words. Such Nouns can't connect with words that incompatible with their grammar or semantics. Grammatical connection is determinate by valence of synsemantical Nouns. The words that nominate object denotations with mutual exclusion can't form the unity.

Conclusions. There are such groups of Noun nominations of a few words: according to the structure: two-component, threecomponent; according to the open / close structure: close, open types; according to the Noun prognostication of position: one directional and two directional; according to morphological method of expression: non prepositional Noun nomination, prepositional Noun nomination, adverbial Noun nomination. At the same time two first groups are divided into such models: non prepositional Noun components in genitive case, in dative case etc.

Key words: semantic unities, semantics, synsemantical Noun, connecting properties of word, Noun nominations of few words.

\section{СПОЛУЧАВАЛЬНІ ВЛАСТИВОСТІ ІМЕННИКА}

\author{
Лебедь Юлія Борисівна, \\ кандидат філологічних наук, \\ завідувач кафедри зарубіжної літератури \\ та основ риторики \\ Вінницького гуманітарно-педагогічного коледжу \\ iulialebed7@gmail.com \\ orcid.org/000-0002-8325-3462
}

Мета. Стаття присвячена сполучувальним можливостям іменника. Функціональний підхід вносить істотні корективи щодо виділення системи синтаксичних одиниць, їхньої ієрархії, функції. Функціональний метод допомагає вирішити синтаксичні завдання, що стосуються структури речень. В українській лінгвістиці є багато досліджень, які присвячені дієслівним можливостям утворювати речення. Мета цієї статті - описати сполучувальні можливості іменника щодо утворення кількаслівної іменникової номінації.

Методи. Основними методами дослідження були: описовий метод; метод порівняння; метод моделювання; метод розподільного аналізу.

Результати. Іменнику належить одне із центральних місць у системі частин мови. Він може позначати предмети й може бути головним компонентом речення. Іменник - один із компонентів, що активно бере участь у реченнєвотвірних процесах.

Більшість смислових єдностей базуються на синсемантичному іменнику, який може позначати об'єктний денотат. Ця властивість сприяє утворенню єдностей різної структури із синсемантичним іменником. Українські синсемантичні іменники утворюються від синсемантичних дієслів, деяких абсолютних іменників із певним значенням та іменників із переносним значенням. Синсемантичні іменники утворюються від дієслів, що означають стан природи.

У кількаслівній іменниковій номінації іменник утворює сильну позицію для залежного компонента. Цей компонент компенсує синсематику іменника. Відповідно до цих залежних компонентів ми можемо виділити такі моделі кількаслівної іменникової номінації: безприйменниково-іменникові / займенникові моделі, прийменниково-іменникові / займенникові моделі, інфінітивні моделі.

Синсемантичні іменники проявляють вибірковість відповідно до залежних слів. Такі іменники можуть поєднуватися зі словами, несумісними граматично чи семантично. Граматичний зв'язок визначається валентністю синсемантичних іменників. Слова, що номінують об’єктний денотат із взаємним виключенням, утворюють єдність. 
Висновки. Існують такі групи кількаслівної іменникової номінації: за будовою: двокомпонентна, трикомпонентна; за структурною відкритісю / закритістю: закритого, відкритого типу; відповідно до прогнозування позиції іменником: односпрямована і двоспрямована; за морфологічним вираженням залежних від синсемантичного іменника слів: безприйменниково-іменникові, прийменниково-іменникові, інфінітивні, прислівникові. У межах кожної із цих груп виділяємо варіанти приіменникових обов'язкових компонентів із властивими їм формальними та семантичними ознаками. Синсемантичний іменник «обирає контекстних партнерів», у поєднанні з якими цілісно реалізує семантику, забезпечує тим самим граматичну й значеннєву правильність, мовну нормативність конструкцій - семантичних єдностей, на базі яких утворюються приіменникові обов’язкові компоненти з відповідним синтаксичним значенням.

Ключові слова: семантичні єдності, семантика, сполучувальні властивості слова, синсемантичний іменник, іменникова кількаслівна номінація.

\section{Introduction}

In modern linguistic science, attention is drawn to the issues that are now at the centre of interest of syntactic theorists and are receiving ambiguous answers.

Functional analysis helps to reflect the verbal nature of the syntax in the language system, its subordination to the two main functions of language - communicative and cognitive - more clearly.

Functional approach makes significant adjustments to the allocation of the system of syntactic units, their hierarchy and function.

In Ukrainian studies there is a significant theoretical and practical development in terms of the study of formalgrammatical, semantic and functional features of the verb (works by I. Vyhovenets, V. Rusanivskiy, A. Zagnitko, O. Melnychuk, K. Gorodenska, N. Ivanitska, S. Ermolenko, J. Andersh, N. Guyvaniuk). Exploring the multilevel nature of the verb, scientists began to distinguish the following classes of verbal vocabulary: "relational" (N. Ivanitska, V. Schmilauer, A. Zagnitko); "Relative", "independent" (L. Shcherba, V. Vinogradov); "Syntemantic" (A. Marti, O. Gulyga, N. Dziubyshyna); "Verbs of open semantics" (R. Haisina, G. Zolotova); "Semantically unsaturated" (W. Jung); "Not sufficient" (M. Mirchenko); "Not closed" (M. Brinkman); "Intentional” (Y. Oravets, R. Mrazek, M. Volodchenkov); "Verb of incomplete predication" (V. Hak).

In Ukrainian studies, the first attempt to distinguish absolute and relative verbs was made by N. Dzyubyshyna, she divided verbs into autosemantic and synsemantic according to their main feature "semantic completeness / incompleteness" (Dzyubyshyna, 1979: 8). A. Zahnitko is inclined to think that the formal-grammatical and semantic-syntactic, as well as the actual syntactic organization of the sentence of the verb structure, depends on the absolute and relative properties of the verb vocabulary (Zahnitko, 2001: 270). Focusing on the formal-syntactic level of the sentence, N. Ivanytska connects the appearance of obligatory distributors in verbs with the inability of such verbs to express the finished meaning with their own phonemic composition (Ivanytska, 1986: 32-34).

Establishing semantic-syntactic classes of words, determining the patterns of lexical content of syntactic constructions, as well as identifying patterns of influence of word compatibility on the syntactic structure of a sentence allows solving the problem of interaction of lexica and syntax.

The Ukrainian language has a rather complex system of word relations. The word compatibility, the realization of its semantics depends on the part-of-speech affiliation, morphological structure, lexical and grammatical features. In our study, the components of Noun nominations of a few words are considered on the basis of the connecting properties of full words at the phrase level. The relevance of the research is due to the need for in-depth study of the semantic potential of the full word.

The noun belongs to one of the central places in the system of parts of the language (Vykhovanets, 2004: 41). Centrality is caused by the property of the noun to denote objects (semantic aspect) and it acts as the main component (formalgrammatical aspect). One of the organizing components of the sentence is the noun.

The purpose of the article is to find out the basic connecting properties of a noun.

The main methods of the study were: a descriptive method that made it possible to thoroughly analyze the binding properties of the noun; comparison method was used to establish the relationship between required and optional components; modelling method - to construct sentences with a sufficient set of components for the sentence as a communicative structure; method of distributive analysis - to identify the connecting characteristics of nouns in order to distinguish synsemantic ones among them.

\section{Semantic unities of noun type}

Noun nominations of a few words are formed on the basis of: two-element semantic unities - subordinate noun phrases with a basic synsemantic noun (відвідування занять, втручання в будівництво, повернення боргу, пошив одягу, проведення дискусії, читання книги) and on the basis of three-element semantic unities with a basic synsemantic noun (надання допомогти малозабезпеченим, забезпечення населення електрикою).

The semantic unity of the noun type is joined by a large number of sysemantic noun words, which together with their dependent word forms form the ground of structures on the basis of which Noun nominations of a few words are formed.

Most noun words that form semantic unities of the noun type are words of a synsemantic nature because of their inability to nominate subject denotes by their own phonemic composition (Admoni, 1973). This property contributes to the formation of noun words of semantic unities of different structure, in which noun synsemantism is compensated by the dependent word forms of other parts of the language, mainly nouns. Synsemantism is peculiar to: a) verbal nouns (deverbatives) (Ivanytska, 1986: 38); b) autosemantic nouns in certain meanings; c) noun words with a figurative meaning. 
The total number of noun words formed from verbs is much smaller than the verbs themselves. There are no verbal nouns formed from the vast majority of autosemantic verbs in the Ukrainian language. This is especially true of impersonal verbs, such as those denoting the state of nature (сніжити, перегриміти, зоріти, замрячити, дніти, віхолити, вітрити, вияснятися) or the physiological state of certain organs of the human body: боліти (about part of the body), терпнути (about the limbs), свербіти (about the body or its parts), німіти (about the body or its part), etc. Absolute impossibility of verb-noun word-forming correlation is revealed by autosemantic verbs to denote the state of nature with prefixes, for example, in a subgroup of verbs with semantics of ingressiveness (завесніти, завечоріти, замжичити, захурделити), intensity (розвеснітися, розгримітися), iteractivity (попогриміти), delimitativity (похмарити), finiteness (передощити). The above-mentioned regularity explains, first of all, the denotative fixity of semantics on the procedural in the complete absence of the subject denotation, and therefore the noun or pronoun in the function of a subset capable / incapable of being transformed into a generic noun (світає $\rightarrow$ світання (чого?)).

Strong positions formed by noun words in noun-type semantic unities have the ability to substitute noun (pronoun) word forms in indirect pronouns without prepositions, which compensate for the synsemantism of noun words: брязкіт машин, виникнення епідемії грипу, володіння зброєю, володіння майном, гавкання собак, газифікація села, запуск ракети, застосування законів, застосування зброї, збирання врожаю, оптимізація вирішення питань збуту сировини, отримання інформації, проблема утилізаиї побутових відходів, проведення слідства, процес поширення інфекції, процес читання, розкрадання землі, розкрадання коштів, служіння народу, співчуття другові, стислість викладу еtс.

Like synsemantic verbs, synsemantic nouns are selective about dependent words with appropriate grammatical and lexical features and cannot be combined with others that are incompatible with their "grammar" or semantics. The grammatical compatibility is limited by the semantic-grammatical (valence) signs of the synsemantic nouns, and their lexical compatibility is denotative. Nouns with violation of structural and semantic laws of semantic unity formation:

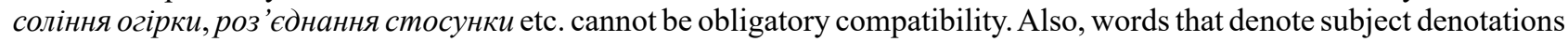
that mutually exclude one another cannot be combined (Ivanytska, 2001): роз'єднання генія, збирання почуттів еtc. Words that have a partial match of seme may be matched.

The semantic unity of the noun type has semes that are necessarily explicated, which leads to binding compatibility of reference words with dependent as compensators for incomplete noun semantics: Атмосфера гаряча, тривожна, вся небезпека і боротьба, вічний упад і підйом, розквіт надії й розлуки, почуття сили й знесилля $і$ безконечно довга дорога <..> (М. Коцюбинський); До найреальніших картин вона додає ліричні покраси, що не раз нагадують симфонії, де враження краєвидів і почування душі зливаються в неподільну гармонію (Леся Українка); Зрозуміння природи для сучасного людства менш істотне, ніж користання з неї (П. Загребельний); Поииреність конфліктів, їхня роль у суспільному житті привертали увагу до них ще із часів глибокої старовини (Із журн.); Свято - ие генеральний огляд сил (В. Винниченко).

\section{Types of Noun nominations of a few words}

There are the following types of Noun nominations of a few words:

- by structure: two-element (споживання иукру), extended structure (здатність відновлення судин мозку);

- on the closed / open structure: closed type (допомога малозабезпеченим), open type (перевірка готовності <...>);

- predicted noun positions: unidirectional (махання руками), bidirectional (вручення премї переможиям);

- according to the morphological expression of the words dependent on the synsemantic noun: noprepositions-noun (збирання врожаю), prepositions-noun (втручання у справу), infinitive (обіцянка прийти), adverb (оранка вручну).

We distinguish the following main groups of models of compound nouns (of several words): without prepositional noun / pronoun, prepositional noun / pronoun, infinitive. Within each of these groups, there are variants of noun mandatory components with their formal and semantic characteristics.

The system of components of Noun nominations of a few words consists of nouns and infinitive word forms used in synsemantic nouns to compensate for their insufficient semantics in the semantic unities of different structures: спроба втручатися у діяльність підрозділу, прагнення до вступу в НАТО, перехід прикметників в іменник, неспроможність до керівництва краӥною, неможливість поспілкуватися з людиною, здатність словосполучення до транспонування у речення, здатність слова до поєднання 3 (повнозначним) словом, залежність слова від властивостей мотиватора, втручання в справи бізнесу, відмова підсудного від зустрічі з адвокатом еtс.

Considering the morphological expression, the dependent component of Noun nominations of a few words is classified according to the corresponding structural models, for example: without the preposition-noun / pronoun components in the genitive case, without the preposition-noun / pronoun components in the dative case, etc. In addition, taking into account the inter-component semantic-syntactic relations, and therefore the syntactic semantics of the obligatory noun component, we distinguish, for example, without preposition-nouns / nouns with object value (object semantics), preposition-noun / pronoun components with a circumstantial meaning (circumstantial semantics), etc.

\section{Conclusions}

Thus, the synsemantic noun "selects context partners", in conjunction with which it implements semantics, thereby providing grammatical and semantic correctness, the linguistic normality of constructions - semantic unities, on the basis of which nouns are obligatory components with corresponding values.

Compulsory noun components are distinguished in the system of noun mandatory components, expressed in the forms of generic, dative, noun, and noun pronouns without nouns.

Further study of models of Noun nominations of a few words will allow determining what syntactic value the abovementioned nominations can express. 
Bibliography:

1. Адмони В. Пути развития грамматического строя в немецком языке. Москва : Высшая школа, 1973.178 с.

2. Вихованець I., Городенська К. Теоретична морфологія української мови : академічна граматика української мови. Київ : Унів. вид-во «Пульсари», 2004. 400 с.

3. Дзюбишина Н. Роль автосемантичних і синсемантичних дієслів у реченні. Організація тексту (граматика $i$ стилістика). Київ, 1979. С. 5-13.

4. Загнітко А. Теоретична граматика української мови : Синтаксис. Донецьк, 2001. 662 с.

5. Іваницька Н. Вплив сполучуваності повнозначних слів на утворення компонентів синтаксичної структури речення. Мовознавство. 2001. № 3. С. 97-103.

6. Іваницька Н. Двоскладне речення в українській мові. Київ : Вища школа, 1986. 167 с.

References:

1. Admoni V.G. (1973) Puti razvitiya grammaticheskogo stroya $v$ nemetskom yazyike [Ways of development of the grammatical system in German]. Moskva : Vyisshaya shkola, 178 p. (in Russian)

2. Vykhovanets I.R., Horodenska K.H. (2004) Teoretychna morfolohiia ukrainskoi movy: Akadem. hramatyka ukr. movy [Theoretical Morphology of the Ukrainian Language: Academ. grammar ukr. language]. Kyiv : Pulsary, 400 p. (in Ukrainian)

3. Dziubyshyna N.Ya. (1979) Rol avtosemantychnykh i synsemantychnykh diiesliv u rechenni [The role of autosemantic and synsemantic verbs in a sentence]. Orhanizatsiia tekstu (hramatyka i stylistyka) - Text organization (grammar and stylistics) (pp. 5-13). Kyiv. (in Ukrainian)

4. Zahnitko A.P. (2001) Teoretychna hramatyka ukrainskoi movy: Syntaksys [Theoretical grammar of the Ukrainian language: Syntax]. Donetsk, 662 p. (in Ukrainian)

5. Ivanytska N.L. (2001) Vplyv spoluchuvanosti povnoznachnykh sliv na utvorennia komponentiv syntaksychnoi struktury rechennia [Influence of full-word word compatibility on the formation of components of a syntactic sentence structure]. Movoznavstvo - Linguistics, 3, 97-103. (in Ukrainian)

6. Ivanytska N.L. (1986) Dvoskladne rechennia v ukrainskii movi [Two-fold sentence in the Ukrainian language]. Kyiv : Vyshcha shkola, 167 p. (in Ukrainian)

Стаття надійшла до редакиії 24.06.2020

The article was received June 24, 2020 